\title{
EROS, CIVILIZATION AND THE BURGER COURT*
}

\author{
Thomas C. GReY†
}

I want to offer an interpretation of one aspect of the Burger Court's decisions concerning sex, marriage and the family. This area of constitutional law is almost entirely the creation of the Burger Court and it seems to puzzle many people. The puzzle is a double one: why did a conservative Court get into this area at all? And once it got in, why hasn't it carried through with its project, by invalidating the laws that interfere with the private sex lives of consenting adults?

The decisions I have in mind have largely been decided under the constitutional "right of privacy" introduced by the Warren Court's decision in Griswold $v$. Connecticut, in which the Court invalidated a Connecticut law prohibiting the use of contraceptives, even by married couples. ${ }^{1}$ Of course, Griswold was not the first contact between the Constitution and the law governing family and sexual relations. In the twenties the Court had invalidated two state laws regulating educational practices as unduly restrictive of parental child-rearing authority. ${ }^{2}$ Then, during the forties, the Court had struck down an Oklahoma sterilization statute under the equal protection clause while observing that marriage and procreation were among "the basic civil rights of man;"3 and had upheld a child labor statute as applied to young religious proselytizers only after observing that there was a "private realm of family life which the state cannot enter." never grouped into a common category before Griswold.

By contrast, the obscenity cases were a recognized collective entity. Since the middle of the fifties, the Court had struggled to establish constitutional limits on the public censorship of pornography. ${ }^{5}$ But obscenity law never fell into the category of sex and the family; rather it was conceptualized by the courts and commentators as a traditional problem of freedom of expression, pitting the police powers against the free exchange of ideas. At least one critic noted that the obscenity problem was more one of regulating sin than of cen-

\footnotetext{
* Copyright $\$ 1980$ by Thomas C. Grey.

$\dagger$ Professor of Law, Stanford.

1. Griswold v. Connecticut, 381 U.S. 479 (1965).

2. Pierce v. Society of Sisters, 268 U.S. 510 (1925); Meyer v. Nebraska, 262 U.S. 390 (1923).

3. Skinner v. Oklahoma, 316 U.S. 535,541 (1942).

4. Prince v. Massachusetts, 321 U.S. 158, 166 (1944).

5. See, e.g., Jacobellis v. Ohio, 378 U.S. 184 (1964); Roth v. United States, 354 U.S. 476 (1957); Kalven, The Metaphysics of the Law of Obscenity, 1960 S. CT. REv.
} 
soring ideas. ${ }^{6}$ But the slippery slope from pornography prohibition to suppression of Boccaccio and Joyce was still a live problem in the fifties and early sixties, and in any case the comforting absolutes of the first amendment provided such solidly literal support for the opponents of obscenity prosecutions that no one accepted the invitation to reclassify the problem as one of morals legislation.

The Griswold decision made a great splash among academics. For one thing, it revived the question of substantive due process and unenumerated rights. But beyond that, the case apparently injected into constitutional law the debate that had arisen out of the recommendations made by the Wolfenden Report and the Model Penal Code against criminalizing private adult sexual behavior. ${ }^{7}$ I say that Griswold had apparently injected this issue into constitutional law because the commentators immediately saw the case that way. In their view, Griswold marked the first step in the constitutionalization of some contemporary version of John Stuart Mill's principle of liberty-perhaps the version then recently proposed by H.L.A. Hart in his much-discussed debate with Lord Devlin. ${ }^{8}$ Mill's principle, of course, was that the only legitimate reason for state coercion is to prevent harm to others. Hart's revision would have weakened the principle to allow paternalistic laws, while keeping Mill's condemnation of purely moralistic restraints, such as the common prohibitions of sodomy, fornication and adultery.

An obstacle to the Millian reading of Griswold was the Court's focus upon marital privacy as the constitutional value infringed by the Connecticut birth control law. ${ }^{9}$ But this obstacle was apparently removed by the Court's 1972 decision in Eisenstadt $v$. Baird, which extended Griswold to strike down anticontraceptive laws as they applied to unmarried adults. ${ }^{10}$ This development was apparently confirmed and strengthened by the 1973 decision in Roe $v$. Wade, which invoked the right of privacy to protect the free choice of unmarried as well as married women to obtain abortions. ${ }^{11}$ The Millian interpretation has been nudged along earlier by the decision in Stanley $v$. Georgia,$^{12}$ in which the Court had combined the right of privacy with freedom of expression to establish that each individual had a constitutional right to possess even obscene material in his home without legal interference. ${ }^{13}$

\footnotetext{
6. Henkin, Morals and the Constitution: The Sin of Obscenity, 63 Colum. L. Rev. 391 (1963).

7. See Wolfenden Report, Report of the Committee on Homosexual Offenses and Prostitution (1963); P. Devlin, The Enforcement of Morals (1965); H.L.A. Hart, Law, Liberty And Morality (1963); Schwartz, Morals Offenses and the Model Penal Code, 63 Colum. L. Rev. 669 (1963).

8. See Appendix.

9. See notes 17-19 infra and accompanying text.

10. 405 U.S. 438 (1972).

11. 410 U.S. 113 (1973).

12. 394 U.S. 557 (1969).

13. For a cogent exposition of the "commentators' position" as it looked after the 1973 cases, see Note, Roe and Paris: Does Privacy Have a Principle?, 26 Stan. L. Rev. 1161 (1974).
} 
Griswold and its progeny were thus read as leading toward a constitutional right of sexual freedom. There was, then, general surprise and dismay when, in 1976, the Court summarily affirmed a lower court decision upholding a Virginia sodomy statute against an attack by adult homosexuals who claimed that, as applied to their private sexual acts, it violated their right to privacy. ${ }^{14}$ For example, my colleague, Gerald Gunther said that the summary treatment of the case was "irresponsible" and "lawless." 15 In an extensive recent study, David Richards asks:

... [H]ow can the Court in a principled way sustain the constitutional right to privacy of married and unmarried people to use contraceptives or to have abortions or to use pornography in the privacy of one's home, and not sustain the rights of consenting adult homosexuals to engage in the form of sex they find natural? ${ }^{16}$

To offer an oblique answer to that question, I want to look at the Supreme Court's own quite different version of Griswold. The Griswold opinions contained no hint of any endorsement of the sexual freedom of consenting adults. Three of the concurring opinions expressly disavowed any notion that the right of privacy cast constitutional doubt on sex laws. ${ }^{17}$ The opinion for the Court, by Justice Douglas, stressed the ancient and sacred character of marriage as the basis for the decision. ${ }^{18}$ The most articulate opinion, Justice Harlan's earlier dissent in Poe $v$. Ullman, which he incorporated by reference into his Griswold concurrence, elaborated an entirely tradition-centered rationale for constitutional protection of marriage. ${ }^{19}$

Much of the Court's subsequent involvement with sex and the family has followed its original stress on tradition as the source of constitutional rights in this area. The Court has, for example, said that restrictions on the right to marry must have substantial justification, though it seems clear that traditional restrictions such as those prohibiting incestuous and polygamous marriage will not be placed in doubt, however little secular or utilitarian justification they may have. ${ }^{20}$ It has upheld the privilege of traditional and conservative Amish communities to have their children excused from the requirements of state

14. Doe v. Commonwealth's Attorney, 425 U.S. 901 (1976), affirming 403 F. Supp. 1199 (E.D. Va. 1975). One judge dissented in the District Court, and Justices Brennan, Marshall and Stevens urged that the appeal should be set for oral argument by the Supreme Court.

15. G. Gunther, Constitutional Law 76 (2 ed. Supp. 1976) (quoting N.Y. Times, Apr. 3, 1976).

16. D. Richards, Sexual Autonomy and the Constitutional Right to Privacy: A Case Study in Human Rights and the Unwritten Constitution, 30 Hastings L. J. 957, 958 (1979).

17. Griswold, supra note 1, at 498 (opinion of Goldberg, J.; constitutionality of adultery and fornication statutes "beyond doubt"); id. at 505 (opinion of White, J.); Poe v. Ullman, 367 U.S. 497, 553 (1961) (opinion of Harlan, J., incorporated by reference in his concurring opinion in Griswold, supra note 1 at 500 ).

18. Griswold, supra note 1 , at 486

19. 367 U.S. $497,551-55$ (1961).

20. Zablocki v. Redhail, 434 U.S. 374 (1978); Boddie v. Connecticut, 401 U.S. 371 (1971); Loving v. Virginia, 388 U.S. 1 (1967). 
compulsory education laws, while indicating that similar privileges will not be extended to progressive or utopian communities, religious or secular. ${ }^{21}$ It has shielded the traditional family from the zoning laws, ${ }^{22}$ while withholding comparable protection from households made up of unrelated persons. ${ }^{23}$ And it has reaffirmed traditional parental authority over children, ${ }^{24}$ though with important exceptions in the areas of contraception and abortion. ${ }^{25}$

At the same time, the Court has given no support to the notion that the right of privacy protects sexual freedom. Not only has the homosexuals' challenge been summarily rejected, but in addition the Court has bypassed a number of chances to make a first incursion into the fantastic array of American laws that have traditionally forbidden virtually all sexual expression except wedded missionary-position intercourse. For example, the Court has within the last decade twice upheld, summarily but with full opinions, two of the ludicrous "crime against nature" sodomy statutes against void-for-vagueness attacks. In the first case, the Court unanimously sustained a Florida statute that had been struck down on vagueness grounds by the state's supreme court! ${ }^{26}$ In the other case, from Tennessee, the defendant was charged with cunnilingus, an act not within the traditional common law definition of sodomy. No Tennessee court had ever construed the Tennessee statute to cover this act. The vagueness challenge was rejected nevertheless, because a Tennessee court had once approvingly cited a Maine decision which had construed Maine's sodomy statute to encompass cunnilingus-even though the Tennessee decision had not referred to that aspect of the Maine case. ${ }^{27}$

21. Wisconsin v. Yoder, 406 U.S. 205 (1972).

22. Moore v. City of East Cleveland, 431 U.S. 494 (1977).

23. Village of Belle Terre v. Boraas, 416 U.S. 1 (1974).

24. Parham v. J. R., 442 U.S. 584 (1979).

25. Carey v. Population Serv. Int'l, 431 U.S. 678 (1977); Planned Parenthood of Missouri v. Danforth, 428 U.S. 52 (1976). See also Bellotti v. Baird, 443 U.S. 622 (1979) (Although the Court strikes down the requirement of parental consent for abortion by a minor, it reiterates that "the parents" claim to authority in their own household to direct the rearing of their children is basic in the structure of our society").

26. Wainwright v. Stone, 414 U.S. 21 (1973). The case involved two habeas corpus challenges to sodomy convictions obtained under the Florida statute, which proscribed "the abominable and detestable crime against nature," with a maximum punishment of twenty years imprisonment. After the convictions became final, the Florida Supreme Court held the sodomy statute void for vagueness, Franklin v. State, 257 So. $2 \mathrm{~d} 21$ (Fla. 1971), but held that its ruling would not be applied retroactively. The Fifth Circuit held that the petitioners in this case should have federal habeas relief, 478 F. 2d 390 (5th Cir. 1973). On the state's appeal of that decision, the Supreme Court summarily reversed, noting that it was not bound by the Florida Court's vagueness ruling. The case is discussed in Note, The Constitutionality of Sodomy Statutes, 45 Fordham L. Rev. 553, 560 (1976).

27. Rose v. Locke, 423 U.S. 48 (1975). In this truly extraordinary case, the Court reached out to grant certiorari and to summarily reverse a decision of the Sixth Circuit, 514 F.2d 570 (1975), granting federal habeas corpus on vagueness grounds. The statute proscribed "crimes against nature, either with mankind or any beast," punishable by a sentence of between five and fifteen years imprisonment, Tenn. Code Ann. $\$ 39-707$ (1955). At common law, sodomy had encompassed only anal intercourse and bestiality. A number of jurisdictions have broadened vague sodomy statutes to include oral intercourse. But whether this includes cunnilingus as well as fellatio 
In another recent case, the Court declined to review a decision upholding the sodomy conviction of a husband and wife for an act of fellatio with each other. The charge was evidently brought because photographs of the act taken by a third party had fallen into the hands of the couple's children, and a conviction for the appropriate offense-child abuse-had been reversed on appeal by the state courts. ${ }^{28}$ In the last case I shall mention, the Court denied certiorari from a decision upholding the discharge of two public library employees for adulterous cohabitation, where the woman had become pregnant and the man had moved in with her before obtaining a divorce from his wife. ${ }^{29}$

These cases strongly suggest that the Court meant what it said in Griswold: that the right of privacy protects only the historically sanctified institutions of marriage and the family, and has no implication for laws regulating sexual expression outside of tranditional marriage. But what, then, is to be made of Eisenstadt and its successor contraception cases, of the Abortion Cases, and of Stanley v. Georgia? Do they not at least establish that the Court has been of two minds in the areas of sex and the family-divided between the traditionalist viewpoint expressed in Griswold on the one hand, and a modern, rationalist, individualist outlook reflecting the perspective of J.S. Mill, Professor Hart,

is an unanswered question in this curious branch of jurisprudence; a number of courts have held that "penetration" is an element of the offense, thus exluding this act, while still others have found that "emission" is required. See Note supra note 26, at $556 \mathrm{n}$. 18, for elucidation, with case citations. Although there was no prior Temnessee ruling on the cunnilingus question, the Supreme Court found that the vagueness problem was solved by Sherrill v. State, 321 S.W.2d 811 (Tenn. 1959), which had quoted from a Maine decision, State v. Cyr, 198 A. 743 (Me. 1938), to the effect that "the prohibition brings all unnatural copulation with mankind or a beast, including sodomy, within its scope." The Maine statute in question had been construed earlier to cover cunnilingus, though the Tennessee court did not mention this.

Justice Brennan observed in dissent that it was "difficult to recall a more patent instance of judicial irresponsibility." 423 U.S. at 54. The case involved not a consensual act, but coerced cunnilingus; the unappealing facts might explain a failure by the Court to reach out to strike down the applicattion of the statute, but the Court's exerting itself to save the conviction is inexplicable except as the expression of a firm resolve to stress the immunity of sexual morals legislation as such from constitutional challenge.

28. Lovisi v. Slayton, 363 F. Supp. 621 (E.D.Va.), aff'd, 539 F.2d 349 (4th Cir. 1973) (en banc), cert. denied, 429 U.S. 977 (1976). The case arose on federal habeas, and the lower courts went to fantastic lengths to sustain the convictions in the teeth of Griswold, which everyone has agreed at the very least prohibits prosecuting married couples for their "unnatural" sex acts. The District Court held that the Lovisis had "waived" their right of marital privacy by their negligence in failing to keep close enough guard over the Polaroid photographs of their sexual acts. The Court of Appeals found "waiver" in the fact that a third person, not part of the marital unit, was present. Both rationales are no more than puns on the perhaps unfortunate term "privacy" that the Court has used to designate the rights involved in Griswold and its successors.

The state conviction of Aldo Lovisi for child abuse was reversed by the Virginia Supreme Court because of a technical error in the charge to the jury. Lovisi v. Commonwealth, 188 S.E. 2d 206 (Va. 1972). Lovisi's step-daughters, aged eleven and thirteen, had testified that they had been present at the orgy, and had taken the pictures. The Lovisis and their sexual partner denied this: the children admitted that they disliked their stepfather and would prefer to see their mother and stepfather in prison so that they could live with their father. See $363 \mathrm{~F}$. Supp. at $626 \mathrm{n}, 3$.

29. Hollenbaugh v. Carnegie Free Library, 99 S. Ct. 734 (1979) (Marshall, J., dissenting from denial of certiorari). 
and the libertarian draftsmen of the Model Penal Code and Wolfenden Report on the other?

I believe that the contraception and abortion cases, and Stanley are, like the general run of the Court's decisions in this area, dedicated to the cause of social stability through the reinforcement of traditional institutions and have nothing to do with the sexual liberation of the individual. The contraception and abortion cases are simply family planning cases. They represent two standard conservative views: that social stability is threatened by excessive population growth; and that family stability is threatened by unwanted pregnancies, with their accompanying fragile marriages, single-parent families, irresponsible youthful parents, and abandoned or neglected children.

The conventions of constitutional adjudication of course demanded that the decisions be justified, not on the basis of social stability, but in the language of individual rights. And so they were. In Eisenstadt, the opinion for the majority of four was a nearly incomprehensible muddle, but out of it emerged this often-quoted sentence:

If the right of privacy means anything, it is the right of the individual, married or single, to be free from unwarranted governmental intrusion into matters so fundamentally affecting a person as the decision whether to bear or beget a child. ${ }^{30}$

This language, taken alone, left open the possibility of finding J.S. Mill's doctrine in the privacy cases. The decision was at least founded on the importance of the choice in question to the individual. But the realm of choice involved was not sexual expression, but procreation, "the decision whether to bear or beget a child." 31 A year later the promise implicit in this formula was redeemed in Roe $v$. Wade. In that case as in Eisenstadt, the Court's opinion stressed the importance of the choice to the individual; but again the choice was not sexual but procreational. ${ }^{32}$

These decisions, if viewed in isolation, thus kept alive the possibility that the doctrine of privacy would be found to incorporate sexual freedom. The Court would only have to find that sexual choices, like procreational ones, were of great significance in the lives of individuals, and that no contrary collective interest required the traditional restrictions. But in Roe, more than in

30. Eisenstadt v. Baird, 405 U.S. 438,453 (1972).

31. Id. Some have thought this passage suggests a right of sexual freedom for the unmarried, the argument running along these lines: the Constitution protects free choice about child-bearing for the unmarried; choices about child-bearing arise only for those who have sex; therefore the Constitution protects free choice about sex for the unmarried. See, e.g., L. Tribe, American Constitutional Law 944 n. 12 (1978). But surely you can have a right to wear motorcycle helmets when you ride a motorcycle, without having a right to ride a motorcycle. There is nothing odd about the idea of criminals having constitutional rights. And the Court itself has continued to insist on the disjunction between the right of access to contraceptives and the right of sexual freedom. See Carey v. Population Serv. Int'l, 431 U.S. 678, 688 n. 5 (plurality opinion of Brennan, J.)

32. Roe v. Wade, 410 U.S. 113, 153 (1973). 
Eisenstadt, there was language that looked away from the individualist reading of privacy. There was great stress on the role of the doctor, the expert; ${ }^{33}$ and there was the awkward attempt at a traditionalist argument, a long passage meant to show that restrictions on abortion were not a cultural or historical universal. ${ }^{34}$

Stanley, too, was at best equivocal on the Millian interpretation of Griswold. On the one hand, the Court did give constitutional protection to private enjoyment of pornography, which is a sort of sexual practice disapproved by the traditional sexual ethic, though harmless in any sense Mill would have recognized. On the other hand, the sexual aspect of the case was supplemented by the first amendment-what the Court protected was reading material, suppressed because of the thoughts it stimulated. Of course, the same could be said of all obscenity prosecutions; and indeed Stanley was widely seen as the precursor of the Court's abandonment of its distinction between obscenity and protected speech. ${ }^{35}$ Finally, the case involved the traditional, proprietary notion of the privacy of the home. Which factors were determinative, which makeweight?

Whatever ambivalence there was in Stanley and Eisenstadt was resolved in 1973, the year of Roe v. Wade. First, the Court refused to extend Stanley to protect the purchase or even the personal transportation of obscene materials. $^{36}$ The earlier decision was treated as meaning no more than that the home was a sanctuary for pornography-the law must allow one to have it there, but not to get it there. Second, in Paris Adult Theater I $v$. Slaton, for the first time the Court explicitly considered the claim that the Constitution protects the right of consenting adults to engage in any sexual practices that cannot be shown to cause concrete harm. The Court decisively rejected the claim, concluding that unverifiable assumptions of social harm are enough to justify sexual prohibitions. ${ }^{37}$ True, the sexual practice in question was commercial, and less private than are most sexual relations. But these factors were barely

33. The Court's formulation of the right to abortion during the first trimester is extraordinary in this regard: "the attending physician, in consultation with his patient, is free to determine, without regulation by the State, that, in his medical judgment, the patient's pregnancy should be terminated. If that decision is reached, the judgment may be effectuated by an abortion free of interference by the State." Id. at 163.

The conception of privacy as a right of physicians to practice their profession without state interference has its origins in Griswold itself; see 381 U.S. at 482 . See also Doe v. Bolton, 410 U.S. 179, 219 (1973) (Douglas, J., concurring); United States v. Twelve Reels, 413 U.S. 123, 127 n. 4 (1973) ("constitutionally protected privacy . . . encompasses the intimate medical problems of family, marriage, and motherhood.") [Emphasis added.]

34. 410 U.S. at 129-47.

35. See, e.g., D. Engdahl, Requiem for Roth: Obscenity Law is Changing, 68 MicH. L. Rev. 185 (1969); Note, The New Metaphysics of the Law of Obscenity, 57 CaL. L. REv. 1257 (1969).

36. United States v. Twelve Reels, supra note 33. The Court had earlier refused to extend Stanley to commercial distribution, United States v. Reidel, 402 U.S. 351 (1971).

37. 413 U.S. $49,57-69$ (1973). 
mentioned, and no hope was held out that truly private and noncommercial sex would be treated differently. Even the dissenters did not urge a right of sexual autonomy, but argued that the Court should abandon its quest for a manageable line between obscenity and protected speech. ${ }^{38}$

In other recent cases where it might at first appear that individuality has been upheld against conventional sexual and familial mores, a second look reveals that values of social cohesion have been promoted. In Boddie v. Connecticut, the Court required the state to waive fees blocking access to divorce. But the decision was explicitly based on the value of marriage (here remarriage) as established in Griswold. ${ }^{39}$ For the Court, divorce facilitates solemnizing and formalizing an otherwise irregular extramarital relationship. Where the Court has invalidated discrimination against illegitimate children, it has not done so on the basis that the parents have done no wrong; the stress has been on the innocence of the children, and behind the language of fairness one senses the stabilizing concern that these children be properly socialized. ${ }^{40}$

To summarize, the Court has consistently protected traditional familial institutions, bonds and authority against the centrifugal forces of an anomic modern society. Where less traditional values have been directly protected, conspicuously in the cases involving contraception and abortion, the decisions reflect not any Millian glorification of diverse individuality, but the stabilitycentered concerns of moderate conservative family and population policy.

The alternative is to see the Court as engaged in the covert promotion of Mill's principle. The failure to carry the principle through, then, must represent a prudential guess that to place the protection of the Constitution behind what most people still reject as unnatural sexual practices would too much strain the Court's limited stock of public good will. Such a theory might indeed explain Doe v. Commonwealth's Attorney ${ }^{41}$ Perhaps the Court has been surprised by the depth and persistence of the opposition to the abortion decisions, and the swing justices were not ready to risk a foray into the explosive issue of gay rights. But if Mill's principle is in the wings, why have no hints of it appeared in opinions? At least why has the Court not taken some first step, perhaps striking down one of the absurd "crime against nature" statutes on vagueness grounds-a decision that would invite little public wrath outside the lunatic fringe?

On my interpretation, the Supreme Court's attitude toward sexual freedom is quite different from that of the liberal academic supporters of modern Millianism. But the Court's own attitude is not adequately captured by terms

38. Id. at 73-114.

39. Boddie v. Connecticut, 401 U.S. 371 (1971).

40. This is perhaps particularly apparent in cases involving welfare, New Jersey Welfare Rights Organization v. Cahill, 411 U.S. 619 (1973) and rights to parental support, Gomez v. Perez, 409 U.S. 535 (1973).

41. 403 F. Supp. 1199 (E.D.Va. 1975), aff'd 425 U.S. 901 (1976). 
like "Victorian" or "Puritan," insofar as they imply simply a devaluation of sexuality. Indeed, the Court can be seen as taking sex more seriously than do the liberals.

Consider a familiar passage in the Court's first obscenity decision. The Court said that obscenity is "utterly without redeeming social importance," so that any benefit that might flow from it was "clearly outweighed by the social interest in order and morality . . ${ }^{42}$ But, the Court made clear, not all explicit discussion of sex was unprotected. Why? Because "sex, a great and mysterious motive force in human life, has indisputably been a subject of absorbing interests to mankind through the ages . . ."43

Sex is, then, not something trivial, but a "great and mysterious . . . force." Obscenity, writing designed to arouse as directly as possible this great and mysterious force, is then not utterly unimportant; it is rather utterly without "redeeming social importance," and it may be suppressed in the name of "the social interest in order . .." To paraphrase a bit, obscenity unleashes the great and mysterious anti-social force of sexuality.

The viewpoint implicit here is not an abstruse or unfamiliar one; indeed it is a view that has been central to modern thought and far more widely accepted in our time than contemporary versions of the liberalism of John Stuart Mill. It is the view identified with Freud, with Marxist theorists, and with the central tradition of social theory stemming from Durkheim and Weber, that modern civilization is built upon repression, particularly the repression of sexual drives.

One of Freud's central themes was that communal life, whether in the family or the larger society, depends directly on sexual repression. First, the maintenance of the family depended on the incest taboo, "perhaps the most drastic mutilation which man's erotic life has in all times experienced." 44 Beyond this, civilization exacted further repressions, increasing with the complexity of the society, since "a large amount of the psychical energy which it uses for its own purposes has to be drawn from sexuality." 45 In the process of bottling up sex and withdrawing the stored energy for social use as work and achievement, Western European civilization has reached a high water mark in repressiveness, accepting as legitimate only heterosexual, genital, monogamous sexuality. Though of course imperfectly enforced, this narrow channel of sexual legitimacy still "cuts off a fair number . . . from sexual enjoyment, and so becomes the source of serious injustice." 46 To defend its draconian restrictions "civilization behaves towards sexuality as a people or a stratum of its population does which has subjected another one to its exploitation. Fear of a

42. Roth v. United States, 354 U.S. 476, 484-85 (1957).

43. Id. at 487.

44. S. Freud, Civilization and Its Discontents 51 (J. Strachey trans., 1961).

45. Id.

46. Id. 
revolt by the suppressed elements drives it to stricter precautionary measures." 47

These restraints are necessary not only so that energy may be deflected to work and creative achievement. The larger community requires that its members be bound to each other by common sympathy; the energy for these bonds can only come from "aim-inhibited libido," erotic energy deflected from sex to desexualized social ties. ${ }^{48}$ These bonds are necessary to counter the power of Eros' ancient enemy, Thanatos, the death instinct, which takes the form of aggressiveness when turned outward:

... [M]en are not gentle creatures who want to be loved ... they are, on the contrary, creatures among whose instinctual endowments is to be reckoned a powerful share of aggressiveness. As a result, their neighbor is for them not only a potential helper or sexual object, but someone who tempts them to satisfy their aggressiveness on him, to exploit his capacity for work without compensation, to use him sexually without his consent, to seize his possessions, to humiliate him, to cause him pain, to torture and to kill him. ${ }^{49}$

And:

Civilization has to use its utmost efforts in order to set limits to man's aggressive instincts ... Hence, therefore, the use of methods intended to incite people into identifications and aim-inhibited relationships of love, hence the restriction on sexual life $\ldots .50$

With this somber view, it is not surprising that Freud placed no very high priority on relieving the "injustices" that attend sexual repression. He saw the history of the world as "essentially a series of race murders;" 51 "we spring from an endless ancestry of murderers, with whom the lust for killing was in the blood." ${ }^{2}$ If man's sexual life was mutilated by civilization, civilization was worth the price.

No other social theorist has placed quite so high a stake on the sexual repressions of modern civilization as did Freud. But every thinker of the great central tradition of the last century's social thought has seen repressed sexuality and the authoritarian family structure as close to the core of our civilization. Conservative theorists have defended repression as necessary; revolutionaries have urged that society would have to be overthrown to free us from its tyranny.

Durkheim mirrored the conservative side of Freud's thought, without any of Freud's therapeutic concern for the injury done the individual by repression. ". . . [S]ociety cannot be formed or maintained ..." he wrote, unless we

47. Id.

48. Id. at 56 .

49. Id. at 58 .

50. Id. at 59 .

51. Freud, Reflections upon War and Death, in Character and Culture 125 (1963).

52. Id. at 129 . 
“. . . do violence to certain of our strongest inclinations." ${ }^{53}$ Ethnography and history reveal "the obscure, mysterious, forbidding character of the sexual act." ${ }^{54}$ Marriage, with its restrictions on sexual freedom, was required to maintain society; where there was easy divorce, there was found the high suicide rate characteristic of anomie and social disintegration. ${ }^{\mathbf{5 5}}$

Weber located much of the motive power behind the creation of capitalism in the coming of Protestant, and particularly Calvinist, religion to Europe. The effect was twofold: first, work was infused with religious significance, and so became a calling; second, Protestant asceticism "turned with all its force against one thing: the spontaneous enjoyment of life and all it had to offer"-this because "[i]mpulsive enjoyment of life, which leads away both from work in a calling and from religion, was as such the enemy of rational asceticism . . ."56 The Puritans strove toward the "strict exclusion of the erotic . . from the realm of toleration." And Weber argued that the "powerful tendency toward uniformity of life, which today so immensely aids the capitalistic interest in the standardization of production, had its ideal foundations in the repudiation of all idolatry of the flesh." 57

What happened when capitalism became established? Weber hinted at the process which his successors were to elaborate: the self-destruction of bourgeois civilization through its own success. As capitalism churned forth material wealth and promoted its characteristic cultural spirit of secular rationalism, it undermined the religiously founded asceticism on which its structures were based and substituted a culture characterized by relativism, materialism and hedonism-a culture ultimately incompatible with the work ethic necessary to sustain productive growth. ${ }^{58}$ Following the classic formulation of this view in Joseph Schumpeter's Capitalism, Socialism and Democracy, ${ }^{59}$ Daniel Bell has recently described the clash between a productive economy and a polity dependent upon work and probity on the one hand, and a consumption economy and culture stressing hedonism on the other. The resulting modern archtype is a moral and cultural schizophrenic-organization man by day, swinger by

53. K. Wolff (ed.), Emile Durkheim, A Collection of Essays, with Translations and a Bibliography, at 338-39 (1960).

54. S. Lukes, Émile Durkheim, His Life and Work, a Historical and Critical Survey, at 533 (1972).

55. Id. at 530-31; Émile Durkheim, Le Divorce Par Consentment Mutuel, Revue PolitiQue ET LitTÉratre, vol. V., series 5, at 549-5 l (5 Mai 1906). Durkheim's tables show that the Paris suicide rate was higher for divorced men than for never-married men. No statistics for women were compiled.

56. M. Weber, The Protestant Ethic and the Spirit of Capitalism 166-67 (T. Parsons trans., 1930).

57. Id. at 169 .

58. Weber quoted John Wesley, who put the thesis concisely: "Religion must necessarily produce both industry and frugality, and these cannot but produce riches. But as riches increase, so will pride, anger, and love of the world in all its branches." Id. at 173.

59. J. Schumpeter, Capitalism, Socialism and Democracy chs. XI-XIV (1950). 
night. ${ }^{60}$ The Weberians have followed Durkheim in stressing the centrality of the family to the motivational structure of bourgeois society; Schumpeter in particular eloquently laments the difficulty of sustaining capitalism in a culture of rootless and often childless apartment-dwellers. ${ }^{61}$

On the other side, the Marxist enemies of bourgeois society have preached a similar message from a different perspective. Engels wrote of the close ties between the patriarchal family, sexual possessiveness and parental authority on the one hand, and the capitalist economy on the other. ${ }^{62}$ His ideas form the basis for a strong strand in Western Marxist thought, particularly when combined with later Freudian ideas, as in the writings of Herbert Marcuse and the early Wilhelm Reich. ${ }^{63}$ These writers have argued that the humane goal of sexual liberation could only come with the destruction of capitalism-a view that must fortify the association of traditional sexual restrictions with existing political and economic institutions in more conservative minds.

Another strand in left-wing thought runs contrary to the standard simple equation of capitalism with sexual and familial repression. On this view, early capitalism requires and hence generates the traditional bourgeois family. But that bourgeois family, close-knit, loving and emotion-laden, albeit authoritarian and repressive, ultimately comes into contradiction with the development of capitalism in its later phases. Late capitalism requires not hardworking inner-directed Puritans, but rootless, compulsive consumers, with no emotional ties except to their own narcissistic pleasures. Against this economic demand, the traditional family poses a model of human group founded on non-market altruistic loving relationships, and hence generates serious dissatisfaction with the soulless late-capitalist marketplace. On this view, associated with the writings of Christopher Lasch, it is the very sexual repressiveness of the family, with its Oedipal rivalries, incest taboos, and castration anxieties, that generates the emotional intensity which sustains the family as a "haven in a heartless world." ${ }^{4}$ This strongly Freud-influenced view, then, sees the sexual revolution as an ideological manifestation of late capitalism, but shares the Weberian view that this development creates a contradiction within bourgeois society.

I have spoken here of major thinkers, but the common core of their thought about the relation between sexual restriction and society is everywhere in the air, today as in the past. For just one example, the current self-

60. D. Bell, The Cultural Contradictions of Capitalism $71-72$ (1976).

61. J. SChUMPETER, supra note 59, at 157-62.

62. F. Engels, The Origin of the Family, Private Property and the State (tran. A. West \& D. Torr 4 ed. 1934).

63. See H. Marcuse, Eros and Civilization (1955); W. Reich, Sex-Pol: Essays, 1929-1934 (1972), particularly, The Imposition of Sexual Morality, id. at 89-249; see also M. Horkheimer, CritıCAL THEORY 99-112 (1972).

64. See C. Lasch, Haven in a Heartless World (1977). For early anticipations of this line of thought, see M. HorkHEIMER, supra note 63, at 114-17. 
help bestseller, How to Prosper During the Coming Bad Years, has an entire chapter entitled "Sin Tax," arguing that the current sexual permissiveness is a major factor in the coming breakdown of the capitalist economy. ${ }^{65}$ The author stresses, like any good Freudian or Weberian, the necessity of a restrictive sexual ethic to the maintenance of a sound child-rearing structure and an effective work ethic.

What would be the features of a contrary attitude, one that would be conducive to the development of a constitutional right of sexual freedom? Such a point of view would have two aspects: First, it would ascribe to sexuality a considerable importance in the lives of individuals; and second, it would hold that the way sexual relations are carried on, at least among consenting adults, has no great effect on the welfare of society outside the sexual sphere, so that it is reasonable to regard adults' sex lives as their own business. It is of course the second of these two elements that the orthodox Freudian tradition denies; sex is a vastly important thing to people, so important that we characteristically deny its importance-but the repression of sex is of even greater importance to the general welfare of society.

Another familiar attitude denies the first element, regarding sex as too trivial a matter to deserve constitutional protection. Thus, Justice Rehnquist has asked rhetorically in his dissent in Carey v. Population Services whether the heroes of Bunker Hill and Shiloh died so that teenagers might have convenient access to contraceptives. ${ }^{66}$ This denigrating attitude toward sexuality is consistent with support for legislative repeal of the traditional sodomy, fornication and adultery laws-on the basis of these laws' failure to serve any important purpose, their unenforceability, and the other familiar arguments against "victimless crime" laws. ${ }^{67}$ The movement to abolish these laws has met with success in recent years, and I suspect that much of the support for their repeal has been based on these practical concerns, not on any notion that sexual freedom is a human right. But the belief that sex laws represent a wasteful intrusion into a trivial aspect of human existence is not the sort of attitude likely to lead judges to hold them unconstitutional.

Who then stands for sexual freedom? Who believes neither that sex is a trivial though somewhat shameful matter, nor that it is a "dark and mysterious force in human affairs" that must be repressed if children are to be properly reared and work is to get done? Here and there one can find spokesmen for such a view; for example it permeates Bertrand Russell's book on sex and

65. H. Ruff, How to Prosper During the Coming Bad Years 159-167 (1979).

66. Carey v. Population Serv. Int'l, supra note 25, at 717. Cf. Young v. American Mini Theatres, Inc., 427 U.S. 50,70 (1976) (opinion of Stevens, J.).

67. In the last fifteen years, twenty-one states have altogether repealed their laws prohibiring homosexual activity by consenting adults, and another thirteen states have reduced the crime from a felony to a misdemeanor. H. Chase \& C. Ducat, Constitutional Interpretation 1156 (1979). 
the family, Marriage and Morals, published in 1929, just a year before Civilization and its Discontents. "Sex is a natural human need like food and drink," wrote Russell. ${ }^{68}$ "Joy of life . . depends upon a certain spontaneity in regard to sex. Where sex is repressed, only work remains, and a gospel of work for work's sake never produced any work worth doing." 69 Modern society suffers a paralyzing preoccupation with sex that "[n]othing but freedom will prevent."70 A sexually obsessed society produces young people who are "stupid, deceitful and timorous," 71 and parents who are "starved, hungry and eager, reaching out to the helpless young for some fragment of the nutriment that has been denied them. ..."72

Something of the same spirit surfaces in Michel Foucault's recent History of Sexuality. ${ }^{73}$ Foucault's paradoxical thesis is that far from repressing a preexisting and natural human interest in sex, nineteenth century European civilization virtually invented sex as a topic of inquiry and concern. And twentieth century efforts to liberate us from our supposedly secret-laden, hypocritical and repressive past represent but another form of ideology, in this case the ideology of the caste of experts in sex and the family, developed to justify their ever-increasing power over private and family life. What the cause of liberty needs today, Foucault would argue, is not more Freudian focus upon sexuality as a dark and mysterious force that secretly rules our lives, but the de-emphasis of sexuality as a special subject matter and its reintegration into the general category of human physical pleasures. He says, "We must not think that by saying yes to sex, one says no to power; on the contrary . . . It is the agency of sex that we must break away from, if we aim . . to counter the grips of power with the claims of bodies, pleasures, and knowledges, in their multiplicity and their possibility of resistance." ${ }^{44}$

Foucault is a master of paradox and irony, and it is a splendid paradox that he echoes a writer who is thought of as carrying the obsession with sexuality to its furthest extent, Norman O. Brown. In Life Against Death, Brown preaches the ideal of a culture in which Freud's death instinct no longer takes the form of aggression, so that there is no need for repression of erotic energy to contain its force. In such a culture, Freud's Eros could reign supreme, and human happiness would be attained in the form of complete libidinal gratification. But in this free society, Eros would itself be freed from the narrow focus on genital satisfaction into which it had been channeled by our socially-imposed repressions. It would expand to encompass the full range of all the sensuous pleasures of which the body is capable. Brown takes his motto

68. B. Russell, Marriage and Morals 291 (1929).

69. Id. at $296-97$.

70. Id. at 292 .

71. Id. at 103 .

72. Id. at 286-87.

73. M. Foucault, I The History of Sexuality: An Introduction (1978).

74. Id. at 157 . 
from Thoreau: "We need pray for no higher heaven than the pure senses can furnish."75

Leaving aside Brown's utopianism, it is clear that his idea of Eros is the same as Foucault's "bodies and pleasures." Thus the ideals of Freud's ecstatic disciple and his ironic critic converge. And they join with the view of the rationalist Bertrand Russell, who thought we should treat sex like the natural desires for food and drink. In these three disparate modern prophets, one can discern the attitude most conducive to enshrinement of sexual freedom among our constitutional rights.

Will we have to wait until the spiritual kin of Bertrand Russell, Norman O. Brown and Michel Foucault make up a majority of the Supreme Court before we see sexually repressive laws invalidated? I believe not. I expect that within a few years fornication and sodomy laws will be found unconstitutional, on something like the very dogma of the right of consenting adults to control their own sex lives that the Court has until now so rigorously avoided. But the real reasons for the decisions will have little to do with any notion in the justices' minds that sexual freedom is essential to the pursuit of happiness.

Rather the decisions will respond to the same demands of order and social stability that have produced the contraception and abortion decisions. Thousands of couples are living together today outside of marriage. The fornication laws, otherwise empty formalities as they are, stand in the way of providing a stable legal framework for handling child rearing and property questions within these unions. ${ }^{76}$ For this reason those laws will be struck down in the jurisdictions which have not legislatively repealed them first.

Similarly, the homosexual community is becoming an increasingly public sector of our society. For that community to be governed effectively, it must be recognized as legitimate. Perhaps something like marriage will have to be recognized for homosexual couples, not because they need it for their happiness (though they may), but because society needs it to avoid the insecurity and instability generated by the existence in its midst of a permanent and influential subculture outside the law. ${ }^{77}$ Effective regulation of the family and community life of gay people will require that the laws which symbolically proclaim their sexual identity illegitimate in the eyes of the larger society must be eliminated. Some of the fierce conservatives in our midst will not see this conservative necessity, and their views will prevail in the legislatures of a few jurisdictions. The Supreme Court will then step in and play its traditional role as enlightened conservator of the social interest in ordered stability, and will strike down those laws, in the glorious name of the individual.

75. N. Brown, Life Against Death: The Psychoanalytical Meaning of History 308 (1959)

76. Cf. Marvin v. Marvin, 18 Cal. 3d 660, 668 n. 4, 557 P.2d 106, 112 n. 4, 134 Cal. Rptr. 815, 821 n. 4 (1976).

77. See Note, The Legality of Homosexual Marriage, 82 YALE L. J. 573 (1973). 


\section{APPENDIX $\ddagger$}

\section{Constitutional Privacy and Sexual Freedom: Law Review Opinion}

A literature survey turned up forty-one law review articles and student notes published between 1965 and 1979 that addressed the relationship between constitutional privacy (as established in Griswold and successor cases) and legal prohibitions of consensual adult sex (as condemned by the Wolfenden Report, the Model Penal Code, and H.L.A. Hart; and as supported, in principle at least, by Lord Devlin). Almost all of these articles and notes found support in the privacy cases for the libertarian position on sexual morals legislation.

The pattern was established in the very first published commentary, the analysis of Griswold in Harvard Law Review's annual summary of the Supreme Court Term. The student authors summarized the opinions in the case and noted that the case might stand only for the sanctity of the marital bedroom, or, somewhat more broadly, for free choice for the married in matters of contraception. A still broader reading would introduce the theme of sexual freedom; Griswold might stand for the "libertarian assumption that if the state has no colorable interest in regulating an area of conduct, it should be barred from doing so. ..." On this assumption, it would not be permissible to justify legal coercion "in terms of sexual morality, without reference to the social consequences of the prohibited conduct." Commentators have read Mill, Hart and the libertarian tradition into the privacy cases ever since with almost no encouragement by the Court. The Court's rigorous abstention from any support for sexual freedom in the privacy cases has been almost universally interpreted as political and unprincipled. A student comment on the Court's 1976 decision in Doe $v$. Commonwealth's Attorney is typical:

The affirmance without opinion of the lower court decision is a setback for those who had hoped the Court would take the logical step from its historic holdings in [Griswold and Eisenstadt ] . . ${ }^{2}$ [emphasis added].

Of the forty-one pieces surveyed, only three could be read as negative or seriously equivocal on the question whether the Griswold-Eisenstadt doctrine, read fairly, supported adult sexual freedom. First, in one of the earliest commentaries on Griswold, Thomas Emerson, who had been winning counsel in the case, observed:

It seems unlikely that the Court would disturb most of the legislation relating to adultery, fornication ... and homosexuality .... It is conceivable that sometime in the future, as mores change and knowledge of the problem grows, all sexual activities of two consenting adults in private will be brought within the right of privacy. ${ }^{3}$

The purely predictive tone of the passage leaves unclear whether Professor Emerson would regard the Court's failure to include sexual freedom within privacy as "unprincipled." Perhaps, as an old legal realist, he is not given to assessments in those terms. Second, a 1971 student note took a narrow view of the implications of privacy doc-

$\$$ My thanks to John Kelly for his help with the Appendix.

1. Note, The Supreme Court, 1964 Term, 79 HARv. L. Rev. 105, 165 (1965).

2. Doe v. Commonwealth's Attorney, 425 U.S. 901 (1976). See also Comment, Doe v. Commonwealth's Attorney: Closing the Door to a Fundamental Right of Sexual Privacy, 53 DeNver L. J. 553 (1976).

3. Emerson, Nine Justices in Search of a Doctrine, 64 Mich. L. REv. 219, 232 (1965). 
trine. Not only would Griswold "have to be extended beyond its present bounds" to invalidate the sodomy laws, but the constitutional prohibitions of establishment of religion and cruel and unusual punishment were both more plausible grounds than privacy for reaching the desirable end of declaring such sexual morals legislation unconstitutional. 4 Finally, another student note, this one a particularly thorough review of privacy case law through 1973, argued that Griswold and Eisenstadt provided at best equivocal support for a right of sexual freedom. ${ }^{5}$

The remaining thirty-eight pieces took the view that the better, natural, principled reading of the privacy cases would bring the sexual relations of consenting adults within the protection of the constitutional right of privacy. A few of them also suggested that at least some sexual prohibitions might nevertheless be upheld, as resting upon a compelling state interest in family stability; ${ }^{6}$ but this is entirely consistent with the broad reading of privacy.

\section{List of Articles Surveyed}

Note, The Supreme Court, 1964 Term, 79 Harv. L. Rev. 103 (1965).

Emerson, Nine Justices in Search of a Doctrine, $64 \mathrm{MICH}$. L. REv. 219,232 (1965).

S. Mosk, Foreword to Project, The Consenting Adult Homosexual and the Law: An Empirical Study of Enforcement and Administration in Los Angeles County, 13 U.C.L.A. L. Rev. 644 (1966).

Project, The Consenting Adult Homosexual and the Law: An Empirical Study of Enforcement and Administration in Los Angeles County, 13 U.C.L.A. L. Rev. 644 (1966).

Note, Privacy after Griswold: Constitutional or Natural Law Right?, 60 N.W. L. REv. 513 (1966).

Comment [Mike White], Constitutional Law-Connecticut Contraceptive Ban v. Right of Privacy, 34 U.M.K.C. L. Rev. 95 (1966).

Comment [Robert N. Harris, Jr.], Private Consensual Adult Behavior: The Requirements of Harm to Others in the Enforcement of Morality, 14 U.C.L.A. L. Rev. 581 (1967).

Comment [Irv S. Goodman], The Bedroom Should Not Be Within the Province of the Law, 4 Calif. W. L. Rev. 115 (1968).

Comment, Regulation of Sexual Conduct by Withholding Government Benefits and Privileges, 3 U.S.F. L. REv. 372 (1969).

Comment, Criminal Law-Consensual Homosexual Behavior-The Need for Legislative Reform, 57 Ky. L. J. 591 (1969).

Comment, Limiting the State's Police Power: Judicial Reaction to John Stuart Mill, $37 \mathrm{U}$. Chicago L. Rev. 605 (1970).

Fisher, The Sex Offender Provisions of the Proposed New Maryland Criminal Code: Should Private, Consenting Adult Homosexual Behavior Be Excluded?, 30 MD. L. REv. 91 (1970).

Note, Sodomy-Constitutional Law-Texas Statute Prohibiting Sodomv is Unconstitutionally Overbroad in Proscribing Private, Consensual Acts of Married Couples, 49 Texas L. Rev. $400(1971)$.

Casenote, Constitutional Law-Sodomy Statutes: The Question of Constitutionality, 50 NeB. L. REv. 567 (1971).

4. Case Note, 49 Texas L. Rev. 400, 405 (1971).

5. Note, On Privacy: Constitutional Protection for Personal Liberty, 48 N.Y.U. L. REv, 670, 734-36 (1973).

6. See, e.g., Wilkinson \& White, Constitutional Protection for Personal Lifestyles, 62 CoRnell L. REv. 563, 595-96 (1977). 
Special Student Contribution, Homosexuality and the Law-An Overview, 17 N.Y. L. F. 273 (1971).

A. Doss \& D. Doss, On Morals, Privacy and the Constitution, 25 U. Miami L. Rev. 395 (1971).

Comment, Criminal Law-Laws Which Prohibit Consenting Adults from Participating in Homosexual Activities in Private, 23 S.C. L. Rev. 816 (1971).

Comment, Sexual Freedom for Consenting Adults-Why Not?, 2 PAC. L. J. 206 (1971).

Note, Victimless Sex Crimes: To the Devil, Not the Dungeon, 25 U. Fla. L. Rev. 139 (1972).

B. Bernstein, Sexual Freedom v. The People of the State of California, 2 U.S.F.V. L. Rev. 1 (1972-73).

Note, On Privacy: Constitutional Protection for Personal Liberty, 48 N.Y.U. L. Rev. 670 (1973).

Comment, Homosexuality and the Law-A Right to Be Different?, 38 Albany L. Rev. 84 (1973).

Note, The Constitutionality of Laws Forbidding Private Homosexual Conduct, $72 \mathrm{MıcH}$. L. REv. 1613 (1974).

Note [T. Baker], Roe and Paris: Does Privacy Have a Principle?, 26 Stan. L. Rev. 1161 (1974).

Comment, Oral Copulation: A Constitutional Curtain Must Be Drawn, 11 SAN Diego L. Rev. 523 (1974).

Comment, Constitutional Protection of Private Sexual Conduct Among Consenting Adults: Another Look at Sodomy Statutes, 62 IA. L. Rev. 547 (1976).

Comment, The Constitutionality of Sodomy Statutes, 45 Ford L. Rev. 553 (1976).

Comment, Doe v. Commonwealth's Attorney: Closing the Door to a Fundamental Right of Sexual Privacy, 53 Denver L. J. 553 (1976).

J. Wilkinson \& G. White, Constitutional Protection for Personal Lifestyles, 62 Cornell L. Rev. 563 (1977).

T. Hindes, Morality Enforcement Through the Criminal Law and the Modern Doctrine of Substantive Due Process, 126 U. PA. L. REv. 344 (1977).

D. Bazelon, Probing Privacy, 12 Gonz. L. Rev. 587 (1977).

D. Richards, Unnatural Acts and the Constitutional Right to Privacy: A Moral Theory, 45 Fordham L. REv. 1281 (1977).

Note, Consent, Not Morality, As the Proper Limitation on Sexual Privacy, 4 Hast. Const. L. Q. 637 (1977).

Comment, Right of Privacy Protects Consensual Heterosexual Behavior, 1977 WAsH. U. L. Q. 337 (1977).

Comment, Constitutional Law-The Constitutional Right of Sexual Privacy, 12 Suffolk Univ. L. Rev. 1312 (1978)

Note, Fornication, Cohabitation, and the Constitution. . , 77 MiCH. L. REv. 252 (1978).

Comment, Right of Privacy-Fornication Statute Held Unconstitutional-State v. Saunders, 27 Buffalo L. Rev. 395 (1978).

J. Eichbaum, Lovisi v. Slayton: Constitutional Privacy and Sexual Expression, 10 Columbia Human Rights L. Rev. 525 (1978-79).

J. Eichbaum, Towards An Autonomy-Based Theory of Constitutional Privacy: Beyond the Ideology of Familial Privacy, 14 Harv. Civil Rights L. Rev. 361 (1979).

D. Richards, Sexual Autonomy and the Constitutional Right to Privacy: A Case Study in $\mathrm{Hu}$ man Rights and the Unwritten Constitution, 30 HAST. L. J. 957 (1979).

Note, The Right of Privacy: A Renewed Challenge to Laws Regulating Private Consensual Behavior, 25 WAYNE L. Rev. 1067 (1979). 